\title{
UJI TOKSISITAS EKSTRAK ETANOL BUAH MERAH (Pandanus conoideus Lam) ASAL MANOKWARI PAPUA BARAT DENGAN METODE BRINE SHRIMP LETHALITY TEST
}

\author{
Safriani Rahman, Riyan Wulansari Puspa Seruni \\ Fakultas Farmasi Universitas Muslim Indonesia
}

\begin{abstract}
A research on Toxicity assay of Extract Ethanol Red Fruit (Pandanus conoideus Lam) upon Brine Shrimp Lethality Test which intended to know the toxic effect of Red Fruit and supposed to determine Lc50 of the Red fruit by method Brine Shrimp Lethality Test. The ethanol ekstrak, was made in various concentration 10, 100, $1000 \mu \mathrm{g} / \mathrm{ml}$. Mean while, for negative control was seawater which made by the same concentration.

In each concentration has put in 10 brine shrimp. Each concentration has put 1 drop of yeast extract as source of food. The volume is added to $10 \mathrm{ml}$, observation is done after 24 hours treatment. Observation result in dead brine shrimp data. From the counted of probit analysis method obtained Lc50 value was that $52,844 \pm 25,679 \mu \mathrm{g} / \mathrm{ml}$. Mean while in negative compare there were not brine shrimp killed.
\end{abstract}

Key words : Pandanus conoideus Lam, Brine Shrimp Lethality Test, Toxicity assay

\section{PENDAHULUAN}

Keanekaragaman hayati yang ada di bumi ini tak hanya digunakan sebagai bahan pangan ataupun untuk dinikmati keindahanannya saja, tetapi juga bermanfaat sebagai bahan untuk mengobati berbagai penyakit. Tanaman yang ada, terutama yang tumbuh di Indonesia dikenal sebagai bahan yang ampuh untuk obat dan digunakan sebagai bahan baku industri obat di Indonesia selain juga sebagai obat-obatan tradisional. Sebenarnya, tanaman yang berguna sebagai obat dapat juga ditemui seharihari.

Salah satu tanaman yang biasa digunakan oleh masyarakat Manokwari Papua Barat pengobatan adalah buah merah (Pandanus conoideus Lam). Buah merah mengandung karotenoid, tokoferol, betakaroten, alfa tokoferol, asam oleat, asam linoleat, asam linolenat dan dekanoat. Senyawa-senyawa tersebut kemungkinan mempunyai senyawa bioaktif yang dapat digunakan dalam dunia pengobatan, misalnya sebagai obat kanker (Budi, 2005).

Senyawa yang diduga memiliki aktifitas antikanker harus diujikan terlebih dahulu pada hewan percobaan. Penelitian ini menerapkan metode Brine Shrimp Lethality Test (BSLT) dengan menggunakan Larva udang Artemia salina Leach sebagai hewan uji. Metode ini merupakan salah satu metode yang banyak digunakan untuk pencarian senyawa antikanker baru yang berasal dari tanaman, selain itu metode ini juga mudah, murah, cepat dan cukup akurat (Nurhayati, 2006). 
Kurangnya penelitian dan pengujian secara ilmiah terhadap buah merah (Pandanus conoideus Lam.) sehingga pemakaian dan dosis pemberiannya belum dapat dipertanggung jawabkan atau masih berdasarkan pengalaman Berdasarkan hal tersebut, maka dilakukan penelitian mengenai uji toksisitas ekstrak etanol buah Merah (Pandanus conoideus Lam.) terhadap hewan uji larva udang Artemia salina Leach dengan metode Brine Shrimp Lethality Test (BSLT).

\section{METODE PENELITIAN}

Jenis penelitian yang digunakan adalah eksperimental, yang merupakan penelitian laboratorium dengan menggunakan rancangan eksperimental sederhana.

\section{a. Pengambilan Sampel}

Sampel penelitian berupa buah tumbuhan buah merah (Pandanus conoideus Lam.) dikumpulkan pada pagi hari sekitar pukul 09.00-10.00 WIT diambil di daerah Manokwari-Papua Barat.

\section{b. Pengolahan Sampel}

Sampel penelitian yang digunakan adalah buah merah (Pandanus conoideus Lam.). Setelah itu dicuci dengan air bersih. Sampel dikeringkan dengan cara diangin-anginkan ditempat yang terlindung dari sinar matahari langsung.

\section{c. Ekstraksi Sampel}

Sebanyak 300 gram sampel simplisia dimasukkan dalam wadah maserasi kemudian ditambahkan etanol $96 \%$ sehingga volume lebih tinggi dari permukaan simplisia, dibiarkan selama 5 hari sambil sesekali diaduk. Sampel disaring kemudian dimaserasi kembali dengan pelarut etanol yang baru dengan volume yang sama dilakukan sebanyak 3 kali. Ekstrak etanol dikumpulkan dan diuapkan hingga diperoleh ekstrak kental.

\section{d. Penyiapan Larva}

Sebanyak 50 gram telur udang (Artemia salina Leach), direndam dalam wadah yang berisi $200 \mathrm{ml}$ air laut pada kondisi $\mathrm{pH} 7$ dibawah cahaya lampu dan dilengkapi dengan aerator pada suhu $25^{\circ} \mathrm{C}$. Telur udang akan menetes setelah 24 jam dan menjadi larva. Larva yang berumur 2 hari (48 jam) digunakan sebagai hewan uji.

\section{e. Pelaksanaan Pengujian}

Sebanyak 200 mg ekstrak kental ditimbang dan dilarutkan dengan etanol 20 $\mathrm{ml}$ sehingga diperoleh konsentrasi $10 \mathrm{mg} / \mathrm{ml}$ sebagai larutan persediaan (stok). Kemudian dipipet sebanyak 10, 100, $1000 \mu \mathrm{g} / \mathrm{ml}$ ke dalam vial, diuapkan. Untuk 
kontrol digunakan air laut, kemudian sebanyak 10, 100, $1000 \mu \mathrm{g} / \mathrm{ml}$ dipipet kedalam masing-masing vial .

Masing-masing vial yang berisi ekstrak etanol dan larutan kontrol dengan konsentrasi 10, 100, $1000 \mu \mathrm{g} / \mathrm{ml}$ dimasukkan 10 ekor larva udang Artemia salina Leach dan volumenya dicukupkan sampai $10 \mathrm{ml}$ dengan air laut. Kedalam tiap vial $10 \mathrm{ml}$ ditambahkan 1 tetes suspensi ekstrak ragi (3 $\mathrm{mg}$ dalam $5 \mathrm{ml}$ air laut) sebagai sumber makanan. Vial-vial uji kemudian disimpan di tempat yang cukup mendapat sinar lampu. Setelah 24 jam dilakukan pengamatan terhadap jumlah larva yang mati. Untuk tiap sampel dan kontrol dilakukan pengulangan sebanyak 3 kali.

\section{HASIL PENELITIAN}

Tabel 1 : Data Hasil Pengamatan Kematian Larva Udang Artemia salina Leach Setelah 24 Jam Perlakuan.

\begin{tabular}{|c|c|c|c|}
\hline \multirow{2}{*}{ Jenis sampel } & \multicolumn{3}{|c|}{ Jumlah larva udang yang mati tiap konsentrasi $\mathbf{\mu g} / \mathbf{m l}$} \\
\cline { 2 - 4 } & $\mathbf{1 0}$ & $\mathbf{1 0 0}$ & $\mathbf{1 0 0 0}$ \\
\hline \multirow{3}{*}{ Ekstrak etanol } & 6 & 6 & 8 \\
\cline { 2 - 4 } & 3 & 4 & 10 \\
\cline { 2 - 4 } & 2 & 4 & 7 \\
\hline Total kematian & 11 & 14 & 25 \\
\hline \%kematian & $\mathbf{3 6 , 6 7}$ & $\mathbf{4 6 , 6 7}$ & $\mathbf{8 3 , 3 3}$ \\
\hline Pembanding air laut & 0 & 0 & 0 \\
\hline Total kematian & 0 & 0 & $\mathbf{0}$ \\
\hline \%kematian & $\mathbf{0}$ & $\mathbf{0}$ & 0 \\
\hline
\end{tabular}

\section{PEMBAHASAN}

Pada penelitian ini dilakukan pengujian toksisitas ekstrak etanol dari buah merah (Pandanus conoideus Lam) dengan menggunakan control air laut terhadap larva udang Artemia salina Leach. Pengamatan dilakukan setelah 24 jam setelah perlakuan dengan parameter kematian larva udang Artemia salina Leach. 
Proses ekstraksi menggunakan metode maserasi dengan menggunakan pelarut etanol yang bersifat semi polar dengan maksud untuk menarik komponenkomponen kimia yang ada dalam sampel. Metode maserasi ini digunakan karena sampel merupakan bahan yang cukup lunak.

Larva udang Artemia salina Leach digunakan sebagai hewan uji ketoksikan disebabkan karena ukurannya yang kecil, sehingga tidak membutuhkan banyak sampel dan daya tahan hidupnya yang cukup baik.

Pembanding air laut dimaksudkan untuk melihat apakah respon kematian hewan uji benar-benar berasal dari sampel dan disebabkan oleh air laut itu sendiri. Digunakan air laut karena untuk menyesuaikan habitat hidup larva udang Artemia salina Leach.

Ekstrak etanol dan pembanding air laut dibuat dengan konsentrasi 10, 100 dan $1000 \mu \mathrm{g} / \mathrm{ml}$ ini dimaksudkan untuk melihat variasi respon yang diberikan. Diujikan pada hewan uji larva udang Artemia salina Leach berumur 48 jam, karena pada umur tersebut larva udang Artemia salina Leach mengalami pertumbuhan yang cepat sehingga diasumsikan sebagai pertumbuhan sel yang abnormal. Sebanyak masing-masing 10 ekor larva udang Artemia salina Leach untuk tiap konsentrasi, sampel diujikan dengan parameter kematian setalah 24 jam perlakuan dan diulang sebanyak 3 kali. Selama pengamatan kondisi ditentukan dengan $\mathrm{pH}$ air laut $7-8$, suhu $25^{\circ} \mathrm{C}$ dan kedalam tiap vial masing-masing diberikan 1 tetes ekstrak ragi untuk mengoptimalkan hasil yang diperoleh. Pemberian makanan dilakukan pada saat pengujian (larva usia 24 jam) karena pada usia 24 jam larva asih memiliki cadangan makanan.

Efek toksik dari masing-masing sampel dapat ditentukan dengan melihat $L_{50}$ nya dari perhitungan data kematian larva udang Artemia salina Leach menggunakan metode analisa probit.

Meyer (1982), menyatakan bahwa suatu senyawa dikatakan aktif jika mempunyai nilai LC50 dibawah $1000 \mu \mathrm{g} / \mathrm{ml}$. Bila nilai LC50 dibawah $1000 \mu \mathrm{g} / \mathrm{ml}$ dinyatakan toksik dan diatas $1000 \mu \mathrm{g} / \mathrm{ml}$ dinyatakan tidak toksik. Hasil yang diperoleh pada penelitian ini yaitu pada ekstrak etanol memberikan hasil $L C_{50}$ sebesar 53,088 $\pm 26,286$ $\mu \mathrm{g} / \mathrm{ml}$ dan pada pembanding air laut tidak memberikan respon. Jadi berdasarkan nilai LC 50 dari ekstrak etanol buah merah (Pandanus conoideus Lam) diperoleh nilai dibawah $1000 \mu \mathrm{g} / \mathrm{ml}$, maka dapat diketahui bahwa sampel uji bersifat toksik. 


\section{KESIMPULAN}

Berdasarkan hasil penelitian dan hasil analisa probit dapat disimpulkan bahwa ekstrak etanol buah merah (Pandanus conoideus Lam) bersifat toksik terhadap larva udang Artemia salina Leach dengan nilai LC $_{50}$ sebesar 52,844 $\pm 25,679 \mu \mathrm{g} / \mathrm{ml}$ (LC50 dibawah $1000 \mu \mathrm{g} / \mathrm{ml})$.

\section{DAFTAR PUSTAKA}

Alam ,G. 2002 .BST Sebagai Bioassay Dalam Isolasi Senyawa Bioaktif Dari Bahan Alam. Majalan Farmasi dan Farmakologi, vol 6.

Anonymous,2008. "http://sn2000.taxonomy.nl/Taxonomicon/TaxonTree. aspx?id=33062". Diakses tanggal 15 November, 2008.

Budi,I.M. Paimin, F.R. 2005. Buah Merah, cetakan 3. Penebar Swadaya, Jakarta.

Ditjen POM. 1986. Sediaan Galenik. DepKes RI, Jakarta.

Hodgson.E.,Patricia E.levi. 2002, A Textbook of Modern Toxicology.

ITIS. 2011. Integrated Taxonomic Information System. (Online) (http://www.itis.gov/index.html) diakses 10 April 2011.

Juniarti.2009. Kandungan Senyawa Kimia, Uji Toksisitas (Brine Shrimp Lethality Test) Dan Antioksidan (1,1-Diphenyl-2-Pikrilhydrazyl) DARI EKSTRAK DAUN SAGA (Abrus precatorius L.) (online) http://journal.ui.ac.id/upload/artikel/10 Edit1 JUNIARTI KANDUNGAN\%20 SENYAWA\%20KIMIA Layou .pdf, diakses 10 April 2011.

Mc. Lauglin.J.E.1991. A Blind Comparison of Simple Benzch Top Bioassay and Human Tumor Cell Cytotoxicities as Antitumor Prescreens, Natural Product Chemistry. Elsivier,Amsterdam.

Meyer, B. N., Ferrigni, N. R., Putman, J. E., Jacbsen, L. B., Nicols, D. E., and McLaughlin, J. L. 1982. Brine Shrimp : A Comvenient general Bioassay For Active Plant Constituents. Plant Medica.

Mudjiman, A. 1989. Udang Renik Air Asin. Brata Karya Aksara, Jakarta.

Mutschler,E. 1999. Dinamika Obat. edisi V, Penerbit ITB Bandung.

Mukono, H.J. 2005. Toksikologi Lingkungan. Airlangga University Press, Surabaya.

Nurhayati. 2006. Uji Toksisitas Ekstrak Eucheuma Alvarezii terhadap Artemia Salina sebagai Studi Pendahuluan Potensi Antikanker (http://.analitik .chem.its.ac.id/attachments/-01 Awik OK .pdf, diakses 20 April 2011).

Priyanto. 2009. Toksikologi, Mekanisme, Terapi Antidotum, Dan Penilaian Resiko. Leskonfi (Lembaga Studi dan Konsultasi Farmakologi), Jakarta. 
Soemirat, Juli. dkk. 2009. Toksikologi Lingkungan. Gadjah Mada University Press, Yogyakarta.

Sumeru, Sri Umiyati, Ir. 2008. http// www.gooogle.com./ Produksi Biomassa Artemia.. (diakses tanggal 10 April 2011)

Tobo, F., 2001. Buku Pegangan Laboratorium Fitokimia I. Laboratorium Fitokimia, Jurusan Farmasi, Fakultas MIPA, Universitas Hasanuddin, Makassar. 